epiphany

Journal of the Faculty of Arts and Social Sciences

International University of Sarajevo

ISSN 1840-3719 / No. 4

Spring 2010

\title{
The Emancipatory Potential in Drabble's The Garrick Year, The Waterfall, and The Realms of Gold
}

\author{
Mohsen Hamlı \\ University of Manouba
}

“I strongly believe," Margaret Drabble told me in 1990, "that every reader is creating the meaning of my novels.... I find this increasingly fascinating; the way the reader alters my perception of what I'm writing, and he indeed alters the book." ${ }^{1}$ In the mid-1980s, she told Olga Kenyon: "none of my books is about feminism because my belief in the necessity of justice for women (which they don't get at the moment) is so basic that I never think of using it as a subject."2 And in 1980, she told Diana Cooper-Clark the following: "I've tried to avoid writing as a woman because it does create its own narrowness. I'm not at all keen on the feminist view that there's a male conspiracy to put women down." 3 Fascinating is that Drabble's quasi-advocation that her novels are more like palimpsests harboring more than one tale or reading blows up her assertion that she is not a feminist. ${ }^{4}$

Margaret Drabble's The Garrick Year (1964) charts the spaces the novel's protagonist Emma Evans creates in response to two megalomaniac men (her husband David Evans and the stage manager Wyndham Farrar) during a year's theatrical season at a provincial festival.

It is "the very essence of provocation and bargaining for domination," which both share, that draws Emma to David Evans during their second decisive encounter in the train. 5 "He looked like an actor," she thought of him before discovering that he was one, "had all the air of self-projection," and seemed rough, 
but his was "roughness that amounted in itself to gloss" (21). David was her challenge.

$[\mathrm{H}] \mathrm{e}$ seemed in himself to be a stock character, Welsh, pugnacious, dark, small, in childhood religion-ridden and now ostentatiously keen on drink and women, and with all this an actor, a selfish drama-besotted actor. (24-25)

But Emma's "rarified, connoisseur's self" soon fades into the reality of house, children, and "this self-evident cliché of a man" (25). Before going to Hereford, for the theatre festival, Emma is compelled to turn down a job she has been willing to accept. Bent upon rooting her in his world and denying her the endeavour to mend her "divided self,"6 David grows hopelessly aggressive, masquerades as "the sole custodian of sexual energy," "some aspect of what he stands for and is committed to as a human being,"8 as often actors do in drama, in his role as Flamineo in The White Devil. His role, as he himself defines it earlier in the novel, is that of "a rotten bastard and a social climber and a pimp" (33); a megalomaniac David/Flamineo who arranges the murder of Isabella (Brachiano's wife), of Camillo (Vittoria's foolish husband), and of his brother Marcello. And to be served right, his mother becomes insane and his mistress Zanche betrays him to Isabella's brother who kills him. Flamineo's role fits David astoundingly well as he finds in Flamineo's the words that "justify" his existence. His dying words, which "had some lines that came closer to him than anything [she] had ever heard him say on stage before," confirm Emma in her resolve to dissent and retaliate: "'I do not look,' he said, clutching at his mock wound, / 'Who went before nor who shall follow me. No, at myself I will begin and end'"' (108-109). ${ }^{9}$

The wall, wardrobe, and marble pillar scenes in the novel (18-19, 39-42, 124-125) reveal the extent to which David is determined to root Emma in her passivity and what she calls her "disturbing traits" and drown her in "anonymity" 
(44). His fury, his oppressive possessiveness, splits them. The more he advances on her space, the more she grows manipulative and accommodates their going separate ways.

David's drive to cow Emma into submission, with all the coercion that drive embodies, is unmistakably phallocentric. His efforts to abstract her as a "passive other" are governed by what seems like a sexual metaphor as are all man's needs, in fact, as is explained by Pierre Guiraud in his Sémiologie de la Sexualité (1978).10 Fulfilling one's needs (food, movement, or sex), Guiraud explains, takes four steps: desire, action, pleasure, and satiation. ${ }^{11}$

\begin{tabular}{|l|l|l|l|}
\hline \multicolumn{1}{|c|}{ Desire } & \multicolumn{1}{|c|}{ Action } & \multicolumn{1}{c|}{ Pleasure } & \multicolumn{1}{c|}{ Satiation } \\
\hline eating & mastication & swallowing & repletion \\
\hline $\begin{array}{l}\text { stretching out } \\
\text { one's arm }\end{array}$ & $\begin{array}{l}\text { movement of } \\
\text { the arm }\end{array}$ & blow & rest \\
\hline intumescence & coitus & ejaculation & detumescence \\
\hline
\end{tabular}

Seen in the light of these terms, the contact or conflict between Emma and David is a symbolic representation of an unconscious sexual image. To our great amazement, though David and Emma are seen some seven times lying on or getting into bed, they do not give us the impression that they have made love (18$19,62,91,95,111,119,144)$. She often pushes his hands off her thighs protesting. With Wyndham, as we will see later, sex is, however, explicit as the affair is initiated by the desire to violate rather than seek sex.

It is true that Emma is unresponsive sexually because she "connect[s] love ... lying on beds and so forth ... with babies,... being tired, ... [and] wanting to go to sleep" (131). But whenever she eclipses David's sexual need, he moves to another stage of need and empties himself, as it were, in an act of violence. This is precisely what happens in the wall, wardrobe, and marble pillar scenes. A blow, as Guiraud argues in the table above, is the equivalent of an ejaculation. And 
disappear, rest, and appease recall the sexual detumescence that follows an ejaculation.

\begin{tabular}{|c|c|c|c|c|}
\hline & Desire & Action & Pleasure & Satiation \\
\hline $\begin{array}{l}\text { Wall } \\
\text { Scene } \\
(18-19)\end{array}$ & $\begin{array}{l}\text { In bed. David } \\
\text { laid one hand } \\
\text { across Emma's } \\
\text { thigh; his hand } \\
\text { pushed; he lost } \\
\text { his temper. }\end{array}$ & He leapt up. & $\begin{array}{l}\text { He beat his fist } \\
\text { on the wall. His } \\
\text { fist went right } \\
\text { into the hollow } \\
\text { middle of the } \\
\text { wall; } \\
\text { extraordinary } \\
\text { feat. }\end{array}$ & $\begin{array}{l}\text { anger } \\
\text { disappeared; } \\
\text { sad mood. }\end{array}$ \\
\hline $\begin{array}{l}\text { Wardrobe } \\
\text { Scene } \\
(39-42)\end{array}$ & $\begin{array}{l}\text { Emma sat down } \\
\text { on the bed and } \\
\text { began to } \\
\text { unbutton her } \\
\text { coat. David } \\
\text { joined her. She } \\
\text { has no desire at } \\
\text { all. }\end{array}$ & $\begin{array}{l}\text { He gave a } \\
\text { wardrobe a } \\
\text { slap. }\end{array}$ & $\begin{array}{l}\text { Emma } \\
\text { swallowing the } \\
\text { wardrobe; felt } \\
\text { David getting } \\
\text { down her gullet } \\
\text { "raw and whole } \\
\text { and hairy." }\end{array}$ & $\begin{array}{l}\text { Their lips } \\
\text { met and rested } \\
\text { together. }\end{array}$ \\
\hline $\begin{array}{l}\text { Marble } \\
\text { Pillar } \\
\text { Scene } \\
(124-25)\end{array}$ & $\begin{array}{l}\text { His hair } \\
\text { aggressively cut } \\
\text { short (an act of } \\
\text { castration), } \\
\text { David is in a } \\
\text { very bad } \\
\text { temper }\end{array}$ & $\begin{array}{l}\text { He advanced on } \\
\text { the pillar; } \\
\text { picked it up in } \\
\text { his arms }\end{array}$ & $\begin{array}{l}\text { He hurled the } \\
\text { pillar down the } \\
\text { stairs to the } \\
\text { garage below: } \\
\text { extraordinary } \\
\text { noise. }\end{array}$ & $\begin{array}{l}\text { David appeased } \\
\text { by his } \\
\text { action. }\end{array}$ \\
\hline
\end{tabular}


The last three chapters of the novel focus on Emma's affair with the stage manager Wyndham Farrar. Like her choice of the hat, the junk, and the marble pillar, Wyndham is picked up "to feed the munching jaws of [her raging] mind" (73). While Wyndham sees only one face of Emma, the readers see two. To him, she is the listening, depending woman. To us, there is beneath the manipulative Emma, who plays the role of the "freak" and the child-like female (142-143), a wild internecine double.

To Emma, the excursion to Wyndham's aunt's cottage, where he spent his childhood, has "an irresistible charm" (113). The charm intensifies as she imagines the "narrow" drives that lead to his aunt's cottage leading her rather to Wyndham's "dark knot."

We wandered round to the back of the house, ... the garden stretched away downhill on the far side, through a jumble of scrubs and bushes, and Wyndham waved a hand in that direction and said:

'That's the river, down there' ... 'It's probably very muddy down there, and as far as I can remember it's all covered with nettles. You'd ruin your stockings.'

'I don't mind about my stockings.'

'Don't you? Let's go and see then.' So I scrambled down the steep bank after him... When we got to the bottom we stood there in the thick wet grass staring at the swirling water... Here I was, in the midst of all the greenery... and I was unnerved by it ...

'It is cold, isn't it, come on, let's go.' He pulled me after him back up the bank and into the cultivated part of the garden.

On the way I stumbled on something soft and brown and frightful, that felt like a dead mouse, but when I bent down to see what it was, I found it was only an apple, a wet and rotten apple, that had lain there since the autumn before. (114-115)

The garden, bush, river, bottom, thick wet grass, trees, greenery, are traditionally-accepted sexual references. ${ }^{13}$ His suggestion to go down there to the 
garden, then to the bottom of the steep bank, waving a hand in their direction is thoroughly sexual. His warning that the "nettles" might "ruin [her] stockings" falls in the same line of thought. And Emma not minding about her stockings anticipates her sexual affair with him later.

Wyndham Farrar is in fact Emma's tool; the guillotine that castrates David's space, not Emma's identity. She "enjoys" sex with him (161), but seeing him horribly shrinking, while "a sort of brisk energy [is] taking possession of [her]," is indeed her real fulfilment (162). Wyndham remains lying in bed "looking dazed"; he is no longer "impressive" and "rational" as he has been before she "lets him in" $(159,161)$. They drink tea and stay eyeing each other. "Eyeing each other" is synonym of "wordless" conflict (148); the kind of thing she is used to as David and her "eyed each other" during that "curious conjunction" in the train compartment (21-22). Her penetrating "stare" (a recurrent term in the novel) and her horribly inquisitive silence horrify Wyndham. The more he stays with her, the more his weakness, his hollowness, and the "sham" he epitomizes are seen mirrored in her stare. In short, she "taunt[s] the penis for its misrepresentation of itself," as Germaine Greer says of "what most 'liberated' women do."14 To Emma, Wyndham is nothing but "a dangerous high-powered object, like his own fast car;" the car she has been proud to ride "in public" to "shock" and be "watched" $(133,137)$. But it is his car, his other phallic symbol, that accidentally pins her against the garage wall and almost mutilates her as David comes back home (166167). David lights on her adultery, as she lighted on his when she found him with Sophy Brent "lying on the packing-cases at the bottom of the stairs (143)," and buries his lot in silence. He is punished with his double.

Equally important in this scene (going with Farrar to his aunt's house) is the fact that it offers Emma the freedom to surmount "indecision" (that "drowned" her male double Julian, 170) and make a decision of her own even though it means being "drowned" in adultery. 
If there is anything that horrifies Emma it is associating her with stupidity and gullibility as are Sophy Brent and the rest of women, in fact, as the old adage she disproves of testifies $(35,145)$. It is in reaction to these images that she becomes eccentric, rigid, frigid, compulsive, neurotic, and masochistic. ${ }^{15}$ And, ironically, she now accommodates these "disturbing traits," not only to protect herself, but also to protect others from herself. She becomes "increasingly aware of [her] own strength" (169-170).

The Waterfall (1969) is the story of a thwarted young mother, Jane Gray, the birth of whose second child occasions the visit of her cousin Lucy and her husband James (the virile man she dreamt of before getting married). Lucy withdraws, but James stays to help her manage her children and mount her bed when her doctor frees her for sexual consummation. The novel's "waterfall" is that flow of passion that characterizes her experience with James and dwarfs her frigidity before a car accident maims him forever.

Jane Gray's parental home is a land of appearance, hypocrisy, and discord. She is the offspring of "malice," "dissension," and "artificial" bond. ${ }^{16}$

Some people conspire to deceive the world and find in their conspiracy a bond, but they did it, I think, with a sense of profound mutual dislike. They presented a united front to the world, because their survival demanded that they should, because they could not afford to betray each other in public: but their dissension found other devious forms, secret forms, underhand attacks and reprisals, covered malice, discreet inverted insults, painful praise. Children are lost in such a land, a land of ha-has and fake onedimensional uncrossable bridges and artificial unseasonal blooms: a landscape civilized out of its natural shape. (57) 
Marriage loomed to her as her only means of escape and deliverance from the "fake bridges" and "artificial blooms" of home. She saw, in the apparently brilliant Malcolm she met at a party, some signs of escape. She thought he incarnated the hope of salvation. She was moved by the prophetic words of his song and the highly-pitched tune of his music. He was silent and timid, but that did not prevent her from seeing in him the angel providence had sent to deliver her. So she helped him transcend his "boredom, and exposure, and social neglect" (89), hoping that he would, in exchange, deliver her from the isolation and abandonment to which her parents had confined her.

Engagement did not show her much of his character; but marriage did. Soon after they got married, she learnt that she had overrated him. He was as ostracized and estranged as she was. Marriage, then, was an altar "garbed in white" that worsened her condition (98-99).

The first pages of the novel focus on this after-marriage "age of inactivity" (7). She has become so inert and frigid that Malcolm "began to suggest ... that [she] might be a Lesbian." As his work (singer) excludes her, he himself becomes "inaccessible to [her] sorrows" (100-101).

Their relationship not only reinforces the sense of division and split between them, but also "transform[s] itself into the very things [she] had sought to escape - loneliness, treachery, hardness of heart" (100). This does not prevent her from giving birth to Laurie three years later $(100,103)$. She sinks deeper "into solitude" and drops one after another the friends that Malcolm might suspect.

One of the key scenes that marks Jane's change is the one describing the panic that seizes her when Malcolm returns home late at night and tries to touch her: "I didn't want him: my body refused to accept him, it refused the act, it developed hysterical seizures, it shut up in panic, it grew rigid with alarm" (110).

Her body becomes uncontrollable. "I tried to cure myself," she says, "I tried to read the right books, but the very sight of the diagrams made me feel ill" (110). 
To fend herself off Malcolm's violence, she covers her head, breathes evenly, and assumes the refuge of sleep. Malcolm "crosse[s] over to the bed and yank[s her] out by one arm, and hit[s her] very hard across the face with the back of his hand."

In the end, he went; he must have slept downstairs on the sofa. In the morning I was covered with bruises: I looked at them with alarm and some pride, as though I was glad that my flesh had made some response to so desperate a statement. (111-112)

That is the end between them. The duplicity that has been characteristic of her parents' relationship becomes typical of her relationship with Malcolm. She has never tried to tell him that his lack of warmth and absence from home are the causes of her sexual frigidity. She does not respond to his accusations that she is both "lesbian" and "unfaithful." A sense of mutually-developed mistrust has led them to their present stalemate.

To surmount grief, Jane writes poetry; "that most rigid, incommunicative art, where the passion and the impossibility exist most nakedly, side by side" (118).

I wrote constantly, badly, with passion, and with flashes of alarming satisfaction, flashes that seemed to shine back at me, reflected from another source of light. The more unhappy I was the more I wrote: grief and words were to me inseparably connected, and I could see myself living out that maxim of literary criticism which claims that rhyme and meter are merely ways of regularizing and making tolerable despair.... the truth is that after Malcolm's departure and before Bianca's birth I was writing more copiously, more fluently than I had ever written before, the ink was pouring on to the sheets like blood. My sublime blood, my sublimated blood. (109-110) 
If misfortune has driven her to repudiate her birth, writing poetry induces her to seek rebirth in another pattern of life. The birth of Bianca, shortly after Malcolm's departure, coincides with a serious effort of Jane to comprehend the confusions and misfortunes that have characterized her life, and to reconstitute "a fictitious form" that would offer her a new identity. "I must act," she tells herself, "I have changed, I am no longer capable of inaction - then I will invent a morality that condones me. Though by doing so, I risk condemning all that I have been" (52-53). ${ }^{17}$

The birth of Bianca becomes a pretext for her own rebirth; a peg on which she attaches what she calls her new "morality" or "ladder." Combined with her delivery blood, the "ink" of poetry (that "was pouring on to the sheets like blood", 109-110) produces, in an atmosphere of overheat (both physical and psychological), a new woman.

The delivery, which is described in the first pages of the novel, takes place at home. Jane's whole attention is seen focused not on Bianca, but on the salvation "this close heat" and "these colours of birth" promise.

Jane, sitting there in the bed with the small newborn child tucked in beside her, could feel the sweat of effort flowing unchecked into the sweat of a more natural warmth. They were waiting, she and the midwife, for the doctor, and for cousin Lucy: the doctor, too late to assist the delivery, was coming to put in the stitches, and Lucy was to sit with her for the night....

She thought that she was happy. It was as though all the waiting and the solitude had resolved themselves into some more helpful expectation, though of what she did not know. Deliverance was at hand. It would be safe to wait, now: it could no longer be missed or avoided. This close heat would surely generate its own salvation.

After a while the doctor came, and stitched her up drawing the curtains nervously to do so, shutting out the witnessing snow ... her eyes were dry and angry, her face red and indignant, protesting against the 
possibilities of desertion and neglect, unwilling to let such things threaten her: but Jane let her whole body weep and flow, graciously, silently submitting herself to these cruel events, to this pain, to this deliverance. (910, emphasis added)

Lucy arrives accompanied by her husband James Otford. But Lucy's physical presence is not as important as what her name suggests to Jane. She has been "established as a femme fatale" in Cambridge, thriving on men, leaving the door of her room always open for admirers and lovers, "taking more than her share," and embarking upon a savage sexual selection: "She was my sister, my fate, my example: her effect upon me was incalculable. Perhaps it was merely the significance of her identity that diverted my attention from [my sister] Catherine" (114).

If Jane is the innocent, modest, withdrawn, vulnerable state, Lucy is the self-possessed, shocking, voracious state. Before the birth of Bianca, Jane sees herself divided, "liv[ing] on two levels, simultaneously, and that there was no contact, no interaction between them." But "in her second childbirth," and when Lucy and James arrive, she sees herself "coming together again... I could no longer support the division ,... my flesh and mind must meet or die" (104, emphasis added).

Lucy is nothing but a step in that ladder or morality Jane intends to manufacture for herself. Though she comes to help Jane surmount loneliness, Lucy withdraws after a few nights leaving James behind to take care of her cousin. There follows, between Jane and James, a period of initiation, repetition, and closeness: a period in which they indulge in a mutual comprehension and discovery (21-22). Towards the end of the "weeks of custom" they spend together (31), James emerges out of his concealment and reticence, sits by her on the bed, and confesses that he "want[s] to be in that bed." 
She felt the easy tears rise in her eyes at the sight of [his closeness and helplessness]... she shut her eyes and turned away, moving over for him as he got into the bed....

When she woke, in the small hours of the night, to the baby's crying, he was asleep, profoundly asleep, and not even the disturbance she made in leaving the bed to collect the baby woke him. As she fed the child, she glanced at him from time to time.... She touched him, through the limp shirt, laying her hand on his averted shoulder: he was hot to touch, his skin burned her through the thin cotton... When she had returned the sleeping baby to her cradle, she leant over him once more, touching his hair, his face, but he started to stir so she turned from him instantly, afraid to wake him.... (32-34)

In the morning, "he turned to her, about to clasp her," desirous, like a baby, to be suckled. But hesitation stops him and he "reached out instead for her hand" to keep it in his. When she allows him to mount her bed and get drowned or soaked, like her, in the hot sea of sweat and dampness, he sees himself dutifully attached to the woman that has kind of mothered him.

The quasi-erotic sexless pattern they have mutually convened upon sleeping at night "side by side ... in the wide, much slept in bed" (39) - creates in her a "flood of emotion" and a flow of an unchecked primitive desire, "unobstructed, like milk" (44-45). So that when her doctor liberates her for sexual consummation, she finds herself totally released from the enclosure in which she has been cloistered. She removes the symptoms of dissension from herself; she removes herself as she has surmised she ought to do (13-14). In justifying her need for James, she creates him as a "sexual aid." Because of its importance, I quote in full the passage that describes the "rebirth" of Jane.

Later, in bed, when she turned to him after the long delays of the day, she heard her own voice cry out to him, inarticulate, compelled, from such depths of need that it frightened her.... Her cry was the cry of $a$ woman 
in labour: it broke from her and her body gathered round it with the violence of a final pang.... she lay there a victim, helpless, with the sweat standing out all over her body: in her head it was black and purple, her heart was breaking, she could hardly breathe, she opened her eyes to see him but she could see nothing, and still she could not move but had to lie there, tense, breaking, afraid, the tears unshed standing up in the rims of her eyes, her body about to break apart with the terror of being left there alone right up there on that high dark painful shelf, with everything falling away dark on all sides of her, alone and high up, stranded, unable to fall: and then suddenly but slowly, for the first time ever, just as she thought she must die without him forever, she started to fall, painfully, anguished, but falling at last, falling, coming towards him, meeting him at last, down there in his arms, half dead but not dead, crying out to him, trembling, shuddering, quaking, drenched and drowned....He could not choose but want her: he had been as desperate to make her as she to be made. And he had done it: he had made her, in his own image.... She was his, but by having her he had made himself hers.... He wanted her, he too had sweated for this deliverance, he had thought it worth the risk: for her, for himself, he had done it. Indistinguishable needs. Her own voice, in that strange sobbing cry of rebirth. $A$ woman delivered. She was his offspring, as he, lying there between her legs, had been hers. (149-151, emphasis added)

This is the "metaphoric waterfall" that transforms Jane.18 James is a man of her own making; summoned from the back of her mind, as we will see shortly, to help her re-deliver herself. Of all people she had known, he is the one who sees "her as she had never been seen before." Both construct an "islanded world" cut out of fictions and fantasies and solidified into fact. 19

Alternating between first- and third-person points of view, the narrative can be seen as a "broken and fragmented piece" reflecting Jane's "fragmented" body and self. Each event is given the chance to be "seen from [various] angles" 
(46). If The Waterfall, as Joanne Creighton suggests, incorporates Jane's "reading of her story," 20 the first-person narrative is thus appropriately devoted to filling the gaps and pointing at the exclusions and misrepresentations left in the thirdperson narrative.

Jane admits that she has "professionally edited" the story (of her affair with James) and, therefore, deleted things and told lies instead. The discretion that such an affair requires vindicates her act. But the new tale, the so-called recounted fabricated one, is artistically honest and credible:

I tried for so long to reconcile, to find a style that would express it, to find a system that would excuse me, to construct a new meaning, having kicked the old one out, but I couldn't do it, so here I am, resorting to that old broken medium....

.... Because I so wanted James ,... I have omitted everything, almost everything except that sequence of discovery and recognition that I would call love. (46)

The two kinds of narration have traded roles: while the first person passages express Jane's love and lust and repudiate "nightmare doubts," the third person passages "articulate" her fears and doubts. ${ }^{21}$

One of the key things Jane mentions in her "reading" of her own story (which offers us another tale, a kind of palimpsest) is a past innocent interest in James's arms, wrists, and cars; that is, in the symbols, according to the Freudian premise, of his virility.

While James is beside her asleep, in that sexless scene described above (3334), the sleepless Jane is "looking back," "drifted away" from her present state, to "those moments" of the past when James was visiting his in-laws; reminiscences inspired by James's "writs" and "the sight of ... his limp hand dangling on the chair arm" (32). 
[In bed] He reached out his hand ... and touched her cheek, and her neck, softly.... He stroked her hair, not seeming to mind if it was dirty and smelled of humanity, and then he touched her shoulder and her back - she was lying on her side, facing him, in the position in which she always slept - and finally she became still, leaving his heavy hand lying on her, sinking her downwards, anchoring her, imprisoning her, releasing her from the useless levity of her solitude. (33, emphasis added)

His presence in her bed, her "possession" of him, the world they are living in, are nothing but "some Brussels of the mind," a foreign yet much-desired condition that must have been stimulated by some past hints (84).

She remembers "him and Lucy at those family gatherings ... one evening, one Christmas Eve, at Lucy's mother's house" (60): James was sitting still, politely, on a small Victorian chair; he "shifted silently the angle of his arm as it rested upon the chair" and, as though by way of "transference," Jane "felt [her] own arm, [her] elbow grating on the harsh weave" (61-62). And when she joined James and Lucy, who had preceded her to the kitchen to wash "the coffee things," she found "James ... drying his hands. His shirtcuffs were turned back from his wrists. I noticed them: his wrists, his hands" (62). The following day, James suggested going for a drive, and they "drove to the sea." Malcolm was with them. They walked on pebbles and threw stones at a post in the water (66). When they got back home, Jane dreamt of the sea, of pebbles, and of the frightening, dangerous speed of James's car. She now sees him, thinking in recollection, as her dangerous, voracious, insatiable desire driving her to a sea of passion. In bed, they drown together "in a willing sea" (45), "in the oceans of our flowing bodies, in the white sea of that strange familiar bed" (67). Whenever he touches "her knee under the sheet," or even her hand, tears "flowed down her cheeks quietly, rising unchecked in her eyes and slowly overflowing like a fountain" (37-38). The stones, thrown at the post in the water, "suggest her hardening of her heart 
toward Malcolm."22 These stones fall in the waters of the violent passion she and James get involved in; stones softened by the "tender shades" of their desires.

And as Jane had already foreseen, an accident, "a false warning," denies her "the white lights that [she] had hoped for" (186]. On his way to Norway where he plans to visit his grandfather and "pass [Jane] off as Lucy" (167), James overtakes a small van "to end up crunched up against a tree on the far side of the road" (184-185). Jane and her children remain "amazingly" unscathed. But James's skull gets "fractured in two places" (193).

The novel ends with James recovering from the concussion, regaining his reflexes, starting to speak, remembering the things related to the journey and the accident, but sexually impotent: "the little, twentieth century death" (238), the "violent stranger" that will "inhabit his body" (190-191). ${ }^{23}$ This is Jane's feminine ending of her tale: James's little death falls like a gimmick from a deus ex machina to counterpoint Jane's thrombosis. For on the eve of their departure to Norway, she discovers a painful "thrombic clot" in her leg due to the contraceptive pills she has been taking. She "could have gone on taking them until they killed her" had not James been sexually maimed. Eleanor H. Skoller argues, in this context, that The Waterfall is given a prosodic, feminine ending where the stress is on the penultimate syllable. "James's recovery from the accident" and return home from the Rehabilitation centre "has the stress or the strong accent in the final pages of the novel, but that is not the end." 24 The penultimate episode stresses the way both lovers are justly treated after Jane has wrenched her nature from its dim desperate course.

Determined to be "on a course of defying nature,"25 Frances Wingate of The Realms of Gold (1975) deserts her husband Anthony Wingate when she discovers that she is "programmed for maternity" (15). A "golden girl" with a lust for competition, adventure, and initiative, she sweats outs her "bad moments" (12- 
$14,17,21,35$ ) by travel, effort, and excavation; and by sleeping "with people for years, on principle almost" $(15,67)$. The power to imagine is thus presented "as an extension of the power to procreate physically, to beget offspring."26 This is how Frances presents herself and how the narrator values her flowing imagination:

I imagine a city, and it exists. If I hadn't imagined it, it wouldn't have existed. All her life, things had been like that. She had imagined herself doing well at school, and had done well. Marrying, and had married. Bearing children, and had borne them. Being rich, and had become rich. Being free, and was free. Finding true love, and had found it. Losing it, and had lost it. What next should she imagine?... She had been as arid as a rock, but she had learned to flow. (34-35)

Interesting is that the more she digs and excavates, the more she becomes wed to all that is revealing of her past, life, personality; a kind of transference that is recurrent in Drabble's novels. More thought and imagination are now going to be invested on her own childhood: another city that longs for resurrection.

One Saturday afternoon, Frances Wingate visits Tockley and her parents' Eel Cottage about which she keeps "Wordsworthian images of glorious infancy"27 and spends the weekend with her brother's family. Late that night, Frances, her brother Hugh, and his son Stephen discuss Freud and Empedocles (c.484-c.424) or death instinct and death wish; a point introduced by Stephen's reference to Salvator Rosa's "painting ... of Empedocles jumping into Etna" (197). Stephen maintains that though Empedocles's sandals were "thrown up out of the crater" after his jump, the act of jumping to prove that he was a god, was in itself significant of some kind of divinity in him. But to Frances and Hugh, the philosopher "was just deluded" (197). Jumping into a volcano to prove that one is immortal is a silly act. We are all concerned, Frances believes, with intimations of immortality in us, with visions of power that allow us to draw "meaning out of 
one abyss or another."28 Drawing meaning out of one thing or another is what distinguishes Frances from the defeated and bankrupt people she has come to know and live with.

But it is not only Empedocles who is pictured "poised ... over a gulf of bankruptcy" (201), then drowned in lava, defeated, and flattened. Janet Bird and David and Stephen Ollerenshaw are also pictured poised over private, selfconstructed craters, and relatively defeated. All of them are Ollerenshaws, of Frances's own blood, made of the same stuff out of which she is made, and related to the same soil, ditches, newts, as she is. Unlike Frances, these three Ollerenshaws do not have the stamina for survival and tenacity; they have inherited their ancestors' deficiencies. Frances is, instead, clinging to action; bent upon draining the family's "diseases" and horrors, rather than passively reproducing them, multiplying them (105).

Janet Bird is Frances's second cousin. Shortly after her marriage to Mark Bird, she discovers that she has been the victim of "some conspiracy ... to make [her] ... believe that marriage was necessary and desirable" and that "society offers pyrex dishes and silver tea spoons as bribes, as bargains, as anaesthesia against self-sacrifice" to keep women "upon the altar, upon the couch, half-numb" (129-130).

But unlike those women who throw these bribes and "protest" (once they regain their senses), Jane remains under the spell of anaesthesia, dulled and hibernated (130). The first major scene that shows this weird side of her is the one in which she entertains Mark's guests. Before they arrive, she is depicted indecisive, not knowing what set of plates to use and what dress or shirt to wear. Frances Wingate, with whom the narrator often identifies, would never mind the guests as her anxieties would "usually [be] forgotten ... in ... the brilliance of her conversation" (157-158). Though "her knowledge [and] her instincts," the narrator specifies, are "better than [Mark's] empty second-hand sterile vulgar jokes," Janet is not allowed any conversation (166). Her husband finds rather 
pleasure in "upsetting" her, in demolishing her arguments if she speaks at all, in "refer[ring] to her in company as 'my barren wife,"' in sending her "upstairs to throttle" the yelling baby that is ruining what he considers his pleasant conversation (163).

Janet hates her home. She hated more or less everything about it.... She hated her own efforts to make things look pleasanter, to give it individuality (as she had put it to herself) ... Once, Janet had cared about such things. She had even been quite good at them: she had had "taste," as her mother called it. She had opinions about shapes and colours, and as a child she had been good at making things. (136-137)

It is in reaction to this ill-treatment that every night Janet 'wishes for a volcano' or an overflowing river that would wash her away from the bed in which Mark is waiting to grab her. There was no escape.

Every night of her life, the same problem. What was she to do, what could she ever do, to escape the moment? There lay Mark waiting to grab her. She hated it, she hated him. She had thought of so many ways out feeling ill, headaches, period pains, backaches.... Oh, she knew all the tricks of avoidance.... No wonder she wished for a volcano or an earthquake, neither of them very likely in this flat terrain. A flood would be more likely; what if the great river Done were to overflow and wash them all away out to the cold North Sea? Sometimes she wished that she could really catch some disabling disease - not a fatal disease, for after all if it were truly death she desired, she had the means to hand. No, what she wanted was some universal disaster that would involve her in its fate, or else some personal release, through paralysis or a stroke, or the threat of heart attacks. (174-175, emphasis added)

These are serious fantasies. She grows "drawn towards disasters," floods, wars, holocausts, and car crashes. But none of these happen. "Things could be better," 
thinks the narrator, "but not for her;" not for the "feeble and wilting" Janet (176177). All she can do is finding relief and satisfaction in "tricks of avoidance."

Janet picked up the ashtray, and stared at the cigarette ends. White crushed cellulose, grey insubstantial ash. She picked up the large scented Swedish candle at her elbow, idly, to look at it more closely, and some molten wax tipped into the pottery ashtray with its pottery sign of the Zodiac. The combination of liquid wax and fag ends and burnt matches was singularly disgusting, but she tipped some more, trying to swamp the fag ends completely, leaving a burning hollow green crater in the wide candle.... She melted more wax and tipped it into her molten green lake. The translucent deep core of the candle flowed more brightly. Mark, upstairs, slammed a drawer in a threatening manner. Thus did he summon her.... She must go up to her appointed, her chosen fate.... She melted more wax, she tipped, she melted.... All the matches were sunk by now in the slowly hardening dead sea of wax, sunk like spars from some small shipwreck. Janet stared at her work with some satisfaction. And then she heard her husband call 'Janet' from upstairs, and blew out the green candle, and carried an ordinary white wax candle from the grocer's with her up to bed. (178-179)

Though there is some satisfaction in it, the trick is after all "pointless." Mark's call from above blows up her dream. The scene is truly representative of the way an insolent husband destroys his wife's efforts to overcome depression and fear and "propitiate" the pangs that are consuming her heart. The narrator's commentary ("She must go up to her appointed, her chosen fate") reflects her (the narrator's) disagreement with what Janet is doing. We expect her to break the chain, go upstairs, and tell Mark that she does not enjoy sex with him; that she is not barren, frigid, and neurotic, as he pretends; that sex and violence are incompatible. But Mark calls "'Janet' from upstairs" and she yields; she cannot 
shake herself off her slow, depressing life (183). He summons her to bed, where he is in wait; to "her chosen fate," to the burning crater of marriage.

Just after having presented Janet yielding to the red crater of marriage, the narrator introduces David Ollerenshaw, Frances's cousin, "staring into ... a small and rather dull crater "(184, emphasis added). David is a geologist for whom the crater is a place where he "meditates" on the "dangerous manifestations of nature" and his masochisms, extremes, and oddities.

The volcano rumbled, heaved, and spat, then sank back again like an old man into its ashen bed. Disappointing.... He had always been fond of the more dramatic, dynamic and dangerous manifestations of nature, a fondness that had led him to related activities, such as pot-holing, rock-climbing, mountain-climbing... his pursuit had taken him to some strange landscapes, and some strange extremes of heat and cold....

He stared down abstractly into the reddish lava, thinking of the world chart in the limp blue Penguin, and as he heard, the volcano rumbled, made a noise like a gravel pit emptying, and spat up, suddenly, a few fairsized bombs. One of them landed at David's feet, and he stepped back sharply.... It would be a very second-rate fate, to be knocked out by an almost-spent volcano, and it would serve him right for wanting to see a bit of action.... Man's life span was too short to be interesting: he wanted to see all the slow great events, right to the final cinder, the black hole. (184-186)

David is a successful geologist who has "harnessed [his] neurosis to a useful end" (259), to the satisfaction of his secret desire to seek out uninhabited lands and "strange landscapes" (185). "Volcanoes," Creighton adds, "satisfy a craving in his soul for the inhuman grandeur of nature .... He is sanguine about man's insignificant place in the large schemes of nature."29 "Man's life," he believes, "is ... a mere breath" and his "part in the scale of creation" is not a "very dignified" one. Standing over the "almost-spent volcano," he is then "agonizing over the death of God" and the insignificance of man. To him, the almost-spent 
volcano that rumbles then sinks back is the image of the debilitated God and the impotent man. But his pursuit and his discoveries do not change anything in him; he does not learn from life. He remains to us, as well as to the narrator, an "impenetrable" and "incomprehensible" character - so much so that the narrator confesses that she does not "have ... the nerve to present ... him in the detail [she] had intended" (184). She cannot "expound upon the difficulties of understanding his 'character' and integrating his 'story' into the narrative." 30 Unlike his geology, Frances's archaeology triumphs: not only because of her discovery of Tizouk and the Saharan routes leading to it, but essentially because she does not neglect to examine the roots that had shaped her personality and fate. David, too, discovers a valley of minerals; but this experience does not elevate him. Frances sees him "eccentric, ... manic," "indefinably odd," a stumbling "small figure" that tries to make superhuman efforts, but that fails $(244,188)$.

While Janet Bird is the victim of marriage and David Ollerenshaw of solitude, Stephen Ollerenshaw, Frances's nephew, is the victim of death instinct.

Having been extremely overwhelmed by his wife Beata's anorexia nervosa and his baby's slow development $(88,91-92,347)$, nineteen-year-old Stephen develops the belief that "living is a crime" (92). It is in this mood of extreme pessimism that we catch him "brood[ing] over ... illness and death." But the sudden and bizarre death of Connie Ollerenshaw, his father's great-aunt, and the scandals that her story reveals in the press devastate him beyond human power. He is described poised "by his gas fire ... like a medieval contemplative," meditating over "mortality, decay, the corruption of flesh, disease. The end of all things" (348-349).

He felt himself on the verge of some revelation. It was sure to come: it needed no artificial invocation. The revelation was one of extreme simplicity. It came to him like a light from heaven. It was better to be dead than alive: this was the knowledge that came to him. It 
seemed to descend upon him personally. Being alive was sordid, degrading, sickly, unimaginable.... One spent one's life in inoculating oneself, swallowing medicaments, trying to destroy disease, and all to no end, for the end was death.... Whereas if one left now, if on leapt now, unsubdued, into the flames, one would be free, one would have conquered flesh and death, one would have departed whole, intact, undestroyed. (349)

Stephen yields to this self-revelation and kills himself and his baby (346). They "disappeared together into the red crater, made one with nature, transformed to black ash" (352). Frances is both shocked and relieved. Shocked by the death, but relieved that none of her children will inherit Stephen's eccentricity. She sees his act, the way he "faced his own nature," an "unwelcome Ollerenshaw trait" that went with him. "It was a revelation that she did not want at all. She would continue to live, herself. He had spared her, and taken it all upon himself" (353). Failing to preserve himself, Stephen directs his aggression against himself and his offspring. The death instinct overwhelms him and destroys his creative instinct, his Life instinct.

Seen in the light of the Empedoclean philosophy, The Realms of Gold dramatizes Frances's movement from alienation and disintegration to unity. Empedocles is believed to have taught that the universe is made of elements (or forces) that are either united by Love or separated by Strife (or Hatred). This is why, he argues, "the universe was in a state of unending change." 31 Love and Strife rule the world by turns.

What has generated Janet's, David's, and Stephen's collapse is a yearning for death, a death wish, to end their miseries. They find life humiliating, degrading, meaningless. Theirs are stories "of inner suffering unrelieved by action," as Empedocles's legend is. ${ }^{32}$ Their efforts to transcend their weaknesses are always short-circuited by a prolonged introspection followed by indecision. When meditating over their "inner sufferings," they are vacillating between doubt and confidence then ultimately confidence gives way to total doubt and 
loss. The three of them are, in effect, victims of a kind of death: whether it takes the form of failed marriage, unsociability, or failure to resist one's death instinct. Each of which is a crater, the cynosure of their life, from which there is no escape.

The world in which these characters live is a Strife-governed world: a world without Love. Janet, for instance, sees home as a place of inertia and paralysis (like Emma of The Garrick Year). In Part Two of the novel (which is devoted to her) Love is suppressed; it is a total deadlock. The whole part is pervaded by Janet's feeling that she is facing a "conspiracy" (129); that her hope lies in her "resisting" this male conspiracy and these "larger forces" $(128,131)$. But her "resistance" fades in meditations and broodings. Mark and his friends are the "enemies" or "the warriors" descending from the hills to invade her space - an image reflected from what she is learning in a modern Bible Class (132). This is the strife that drains "certainty ... out of her like water from a cracked cup" (159). Hers is a life of "disasters" and "explosions" (133-134): a life in which she sees herself "nothing" (131).

While Part Two is devoted to Janet's stasis, the other remaining parts of the novel portray Frances's moments of strife, depression, and loss (Part One), her endeavour to make herself flow (Part Three), and her final deliverance and reintegration (Part Four).

It is in Part One of the novel that Frances confronts a Strife-governed world: she sees herself a heroine on her way "to the gallows" (11), a mother programmed for death. The whole part is permeated by her "sense of loss" and grief (14): loss of lover (Karel), of the postcard sent to him, of her wisdom tooth. The postal strike "may be seen as a form of Strife, in some more ordinary sense than in Empedocles." 33 Her toothache, the dislodged filling, and the developing lump in her breast (that has been extirpated) make her sense herself "disembodied" and fragmented (58-59). Estranged from her lover and from her 
roots (while in Adra), Frances imagines herself "in a dry crater" where "love and understanding are beyond her" (59). It is in this Part One that we see her lying "inert," standing in the debris of a strife-destroyed life, like Joy (Karel's wife) in "the misery of marital divorce" $(73,77)$. Lying inert only until she receives a message that Karel still loves her, and the Strife-governed world that has been collapsing gives way (in Part Three) to a Love that allows things to resume their natural course and Frances's imagination to flow again. It is only then that Frances finds the energy to build the future of Adra, that she discovers the tin find and David Ollerenshaw, and that the postcard she sent from "her dry volcano" is finally released to reach Karel. The Empedoclean love with its sense of unity and reintegration is fully developed in Part Four when Frances, who comes back to England for her nephew's funerals, discovers her roots and more Ollerenshaws.

The scene in which she visits Mays Cottage where Connie has been found dead is a kind of last act in Part Four. Connie's abode and the scandals that have been associated with it since the discovery of Connie's corpse are the volcano that has worsened Stephen's condition and drawn him to end his life. Unlike the other Ollerenshaws, Frances is not ashamed of Connie's "volcanic" history that the papers have generously laid out for the public. Connie had tried to do what was not expected of a woman but failed.

Constance Ollerenshaw had lived simply and madly; there were no corrugated iron roofs covering her leaking rafters. A terrible purity marked the scene, and Frances approached it without fear ...

On the key ring, there was a key to the black desk. She lit her candle, for it was now dark, and unlocked the desk, to see what was there.... it was full of things, ... Bits of paper, letters, photographs, medals, buttons, sewing eggs, bobbins, brooches, rings, old tickets, coins, pins, and bits and pieces of a life time - of more than a lifetime, she realized, as she started to go through them, for there were records reaching back into the dim reaches of the dusty Ollerenshaw past, before dead Constance had been born. Ill-spelt letters in spidery 
script announced a death in the family in Lincoln in 1870, a birth in Petersborough in 1875. Nearly as indecipherable as hieroglyphics, nearly as sparse in their information as Phoenician shopping lists, they contained a past, a history. $(303,305)$

Frances reads "the dusty Ollerenshaw past:" how out of it some gifted Ollerenshaws (Frances and her father) have escaped; propelled by ambition. They are "the blessed," "the lucky," the persevering lot (306). Out of scraps, photographs, mementoes, and letters, Frances builds Connie's story. Constance was lucky, too: "one of the lucky" females of her time: she "learned to read and write," "had admirers," and an illegitimate child that died (307-308). Frances finds promises from the child's father (an American seaman and singer who died in an accident) to "speak with the vicar" about their affair. And the imaginative archaeologist speculates about the confusion Constance's "seducer, con man, vacillator, lover, traitor" must have spread in Tockley. "Lost love, rejection, puerperal fever, guilt, interfering vicars, the death of a loved child, persecution by parents" (308). This is the crater that had ruined Constance and dwarfed the younger Ollerenshaws.

Frances is, instead, pleased to discover that she succeeds where Connie had failed. Great-aunt Connie had lived alone, victim of "the caged days" (329), of social persecution. She had fallen from the stairs, broken her leg, and "dragged herself around for some time, eating what was in reach, and then had died" desolate, neglected (291-292). But Frances "would perhaps live here, taking over what Connie had left off" (309-310) and resisting with all her might defeat and sterility. The volcanic tale from which the other Ollerenshaws have shrunk becomes for her the stimulus to be fiercely different from what is expected of her.

\section{Conclusion}

To be sane and balanced, Drabble's three novels studied in this paper demonstrate, women have to seek forms of liberation and reject the roles that 
debilitate them. Rejection is indeed their key term or attitude that allows them to see themselves distanced from the authority of men.

Before marriage, home and mother are the sources of meekness and subordination. The mother is the symbol of subordination all the heroines want to keep clear of. In hating their home, they fulfill an inner desire to revolt against what is seen as their fate. The domestic sphere before marriage is, for all the heroines, a cage that does not promise better days. Escaping it becomes a must.

To escape mother's home, they get married and, unexpectedly, involved in a struggle for marital power they have never thought of. The invigorating power of love they have all dreamt of and learnt about in books fades in the light of reality. None of the protagonists is satisfied with her husband; none of them is decently treated as wife or partner; all of them accuse their husbands or exhusbands of violence and abusive language. And all of them experience a second split (a divorce or separation from their husbands) after a first split from their parents.

Separation, divorce, betrayal, adultery, hysteria, neurosis are the immediate causes of deception in marriage. But other reactions, truly feminist in nature, appear. The first of these is turning the marital split into an invigorating act: Emma Evans exploits her churning silence and inquisitive gazes to explore man's megalomania. Jane Gray makes of poetry her rhetoric of exploration (digging for the past pleasures that can alleviate the present adversities). Frances Wingate explores the family roots and mends herself and others. All of them, in short, transcend their husbands' accusations of sterility.

A woman who has learnt how to resist and win tries to help other women do the same. We begin to see the voice of the central character eager to communicate with other females. Emma sympathizes with the girls David ridicules; Jane writes about her experience; and Frances tries to convert Janet to her case. There is in their attitudes, in their choices, a meaning, a literature that influences their friends. 
Confession of sexual experience (that there is nothing illicit or disgusting in sexual enjoyment) is also seen characteristic of Drabble's principal characters. Such discourse or intercourse brings about a healing effect. The older the characters, the more urging is this discourse seen. There are more confessions of sexual experience in the last novel than in the one that precedes it, and so on. To all the characters, "understanding [sex] is finding the proper mate," 34 as most feminists think. And the proper mate is the one who happens to fill in the gap left by the ex-partner; but who comes only on her terms.

The emancipatory potential of Drabble's novels cannot be denied. Though they do not claim overthrowing the patriarchal order, the novels chart feminist spaces and show women how to resist being deprived of their freedom and identity. As marriage is the source of women's plights, and without calling for discarding it, Drabble makes it clear that love exists without marriage. She shares, moreover, Greer's view that the "joy of the struggle" lies in "the sense of purpose, achievement, and dignity"35 and that there is no recipe for all women to follow to be free. Each woman devises her own form of revolt to withstand the form of oppression she is faced with. 


\section{Notes:}

${ }^{1}$ Mohsen Hamli, personal interview, 26 July 1990.

${ }^{2}$ See Women Novelists Today: A Survey of English Writers in the Seventies and Eighties (London: The Harvester Press, 1988), 85.

${ }^{3}$ See Interviews with Contemporary Novelists (London: Macmillan, 1986), 47, 51-52. For the difference between women-centered novels that are feminist and women-centered novels that are not, see Rosalind Coward, "Are Women's Novels Feminist Novels?," in The New Feminist Criticism: Essays on Women, Literature, and Theory, ed. Elaine Showalter (London: Virago, 1985), 225-239.

${ }^{4}$ Joanne V. Creighton, Margaret Drabble (London and New York: Methuen, 1985), 30.

${ }^{5}$ The Garrick Year (London: Penguin, 1964), 22. References to this work will henceforth be given parenthetically in the text.

${ }^{6}$ Ellen Cronan Rose, The Novels of Margaret drabble: Equivocal Figures (Totowa, N.J.:

Barnes \& Noble, 1980), 14.

${ }^{7}$ Germaine Greer, The Female Eunuch (London: MacGibbon \& Kee, 1970), 18.

${ }^{8}$ L.C. Knights, "Personality and Politics in Julius Ceasar," 1965; rpt. in Shakespeare: Julius Ceasar, ed. Peter Ure (London: Macmillan, 1969), 129.

${ }^{9}$ The original lines from Flamineo's dying speech run as follows:

I do not look

Who went before, nor who shall follow me;

No, at myself I will begin and end.

See John Webster's The White Devil, in Three Plays (rpt. London: Penguin, 1972), V, vi, 154156.

${ }^{10}$ Sémiologie de la Sexualité (Paris: Payot, 1978), 95. All translations from this work are mine.

${ }^{11}$ The desire, or the moment of need, of the mobilization of tendency, and the accumulation of energy; the action, or the implementation of the tendency, the application of the energy; the pleasure, or the satisfaction, the moment the energy is released, the desire accomplished, and the need fulfilled; the satiation, or the moment the energy is demobilized. Sémiologie de la Sexualité, 95.

${ }^{12}$ Sémiologie de la Sexualité, 96.

${ }^{13}$ Sémiologie de la Sexualité, 116.

${ }^{14}$ The Female Eunuch, 318.

${ }^{15}$ Creighton, Margaret Drabble, 50.

${ }^{16}$ The Waterfall (London: Penguin, 1969), 48, 56. References to this work will henceforth be given parenthetically in the text. Drabble refers to The Waterfall as "the most female of all my novels.” See Ellen Cronan Rose, "Feminine Endings - And Beginnings: Margaret Drabble's The Waterfall," Contemporary Literature, 21 (Winter 1980), 81.

${ }^{17}$ Gayle Greene, "Margaret Drabble's The Waterfall: New System, New Morality," Novel, 22, 1 (Fall 1988), 45-65.

${ }^{18}$ Creighton, Margaret Drabble, 60.

${ }^{19}$ Creighton, Margaret Drabble, 63.

${ }^{20}$ Creighton, Margaret Drabble, 56.

${ }^{21}$ See Ellen Peel, "Subject, Object, and the Alternation of First- and Third-person Narration in Novels by Alther, Atwood, and Drabble: Toward a Theory of Feminist Aesthetics," Critique: Studies in Modern Fiction, 30, 2 (Winter 1989), 115. See also Caryn Fuoroli, "Sophistry or 
Simple Truth? Narrative Technique in Margaret Drabble's The Waterfall," Journal of Narrative Technique, 11, 2 (Spring 1981), 110-124.

${ }^{22}$ Lynn Veach Sadler, Margaret Drabble (Boston: G.K. Hall, 1986), 47.

${ }^{23}$ Gayle Greene writes that "Probably James would not have died [sexually maimed] if Jane had refused him.” See "Margaret Drabble's The Waterfall: New System, New Morality," 53.

24"The Progress of a Letter: Truth, Feminism, and The Waterfall," in Critical Essays on Margaret Drabble, ed. Ellen Cronan Rose (Boston: G.K. Hall, 1985), 122-23. See also Ellen Cronan Rose, "Feminine Endings - And Beginnings: Margaret Drabble's The Waterfall," 8199.

${ }^{25}$ The Realms of Gold (London: Penguin, 1975), 12-13. References to this work will henceforth be given parenthetically in the text. Drabble borrows the title of the novel from John Keats’ poem "On First Looking into Chapman's Homer” (1816, emphasis added):

Much have I travelled in the realms of gold

And many goodly states and kingdoms seen;

Round many western islands have I been

Which bards in fealty to Apollo hold.

26 "A Vision of Power in Margaret Drabble's The Realms of Gold," in Critical Essays on Margaret Drabble, ed. Ellen Cronan Rose, 136.

${ }^{27}$ Sadler, Margaret Drabble, 94

28 "A Vision of Power in Margaret Drabble's The Realms of Gold," 135.

${ }^{29}$ Creighton, Margaret Drabble, 88.

${ }^{30}$ Creighton, Margaret Drabble, 84. See also Cynthia A. Davis, "Unfolding Form: Narrative Approach and Theme in The Realms of Gold," Modern Language Quarterly, 40 (1979), 390402.

${ }^{31}$ See "Empedocles" in The Oxford Companion to English Literature, ed. Margaret Drabble (London: OUP, 1985).

${ }^{32}$ Walter E. Houghton commenting on Matthew Arnold's Empedocles on Etna in The Victorian Frame of Mind 1830-1870 (New Haven and London: Yale University Press, 1957), 335.

${ }^{33}$ Susanna Roxman, Guilt and Glory: Studies in Margaret Drabble's Novels 1963-1980, 39.

${ }^{34}$ Rosalind Coward, “Are Women's Novels Feminist Novels?,” 234.

${ }^{35}$ The Female Eunuch, 20, 331.

\section{References:}

Cooper-Clark, Diana. Interviews with Contemporary Novelists. London: Macmillan, 1986.

Creighton, Joanne V. Margaret Drabble. London and New York: Methuen, 1985.

Fuoroli, Caryn. "Sophistry or Simple Truth? Narrative Technique in Margaret Drabble's The Waterfall.” Journal of Narrative Technique, 11, 2 (Spring 1981), 110-24.

Greene, Gayle. “Margaret Drabble’s The Waterfall: New System, New Morality.” Novel, 22, 1 (Fall 1988), 45-65.

Greer, Germaine. The Female Eunuch. London: MacGibbon \& Kee, 1970.

Guiraud, Pierre. Sémiologie de la sexualité. Paris: Payot, 1978.

Kenyon, Olga. Women Novelists Today: A Survey of English Writing in the Seventies and Eighties. London: The Harvester Press, 1988. 
Rose, Ellen Cronan. The Novels of Margaret Drabble: Equivocal Figures. London: Macmillan, 1980. . "Feminine Endings - And Beginnings: Margaret Drabble’s The Waterfall." Contemporary Literature, 21 (Winter 1980), 81-99. ed. Critical Essays on Margaret Drabble. Boston: G. K. Hall, 1985.

Roxman, Susanna. Guilt and Glory: Studies in Margaret Drabble's Novels 1963-1980. Stockholm, Sweden: Almqvist \& Wiksell International, 1984.

Sadler, Lynn Veach. “'The Society We Have:' The Search for Meaning in Drabble's The Middle Ground.” Critique: Studies in Modern Fiction, 23, 3 (1982), 83-93. . Margaret Drabble. Boston: G. K. Hall, 1986.

Showalter, Elaine. A Literature of Their Own: British Women Novelists From Brontê to Lessing. Princeton: Princeton University Press, 1977. , ed. The New Feminist Criticism: Essays on Women, Literature, and Theory. London: Virago, 1985. 